\title{
CONOCIMIENTOS, ACTITUDES Y PRÁCTICAS DE MADRES DE ESCOLARES CON RESPECTO A LOS FRIJOLES1
}

\section{KNOWLEDGE, ATTITUDES AND PRACTICES OF MOTHERS OF SCHOOL CHILDREN WITH REGARDS TO BEANS ${ }^{1}$}

\author{
Adriana Murillo ${ }^{2}$, Shirley Rodríguez ${ }^{3}$
}

\begin{abstract}
RESUMEN
Conocimientos, actitudes y prácticas de madres de escolares con respecto a los frijoles. Este es un estudio cualitativo que se realizó como parte de un diagnóstico previo a una Campaña educativa orientada a promover el consumo de frijoles. En el estudio se determinaron los conocimientos, actitudes y prácticas de las madres de escolares con respecto a los frijoles, utilizando para ello grupos de discusión y entrevistas semiestructuradas. El estudio mostró que la población tiene conocimientos, actitudes y prácticas adecuadas e inadecuadas con respecto a los frijoles. Hay gran variabilidad en las prácticas que aplican y se detectaron algunas que afectan el valor nutritivo de los frijoles. También se encontraron conocimientos erróneos y falta de información en las participantes, principalmente en lo referente al valor nutritivo y a los beneficios que ofrecen los frijoles. Los conocimientos, las actitudes y las prácticas adecuadas o positivas favorecen el consumo de frijoles. Por el contrario, aquellas inadecuadas pueden constituir barreras que limitan su consumo e interfieren con el aporte nutricional que este alimento puede proveer a la población.
\end{abstract}

Palabras claves: consumo de frijoles, conocimientos, actitudes y prácticas, hábitos alimentarios y grupos de discusión.

\begin{abstract}
Knowledge, attitudes and practices of mothers of school children with regards to beans. This is a qualitative study, carried out as a preliminary step before developing an educational campaign aimed at promoting bean consumption. Knowledge, attitudes and practices of mothers of school children with regards to beans were determined in the study, using discussion groups and semi-structured interviews. The study showed that some of the people's knowledge, attitudes and practices with regards to beans are adequate, while others are inadequate. There is a great deal of variability in people's practices, and some of them affect beans' nutritional value. Mistaken beliefs and lack of information were also found among participants, mainly with regards to the nutritive value and benefits provided by beans. Adequate or positive knowledge, attitudes and practices favor bean consumption. On the contrary, those that are inadequate may represent barriers that limit their consumption. Therefore they might interfere with the nutritional contribution that this food could provide to the general population.
\end{abstract}

Key words: bean consumption; knowledge, attitudes and practices; alimentary habits, discussion groups.

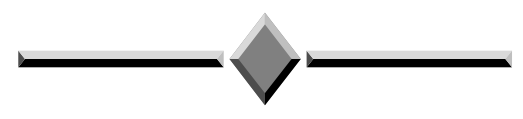

1 Recibido para publicación el 3 de agosto del 2004. Este artículo se deriva de la investigación desarrollada en el Proyecto "Campaña educativa para incrementar el consumo de frijoles", de la Escuela de Nutrición de la UCR, inscrito dentro del proyecto macro "Mejoramiento de la Digestibilidad del Frijol", CITA-UCR, bajo el auspicio del Programa Bean/Cowpea CRSP; USAID Grant DAN-G-SS-86-0008-88.

2 Escuela de Nutrición, Universidad de Costa Rica. E mail: enuasucr@cariari.ucr.ac.cr.

3 Escuela de Nutrición, Universidad de Costa Rica.

\footnotetext{
1 Received for publication on August 3, 2004. This article is the result from the investigation carried out as part of the project "Educational Campaign to Increase Bean Consumption", from the University of Costa Rica's Nutrition School, which is part of the macro-project "Improving Digestibility of Beans", CITA, UCR, sponsored by the Bean/Cowpea CRSP Program; USAID Grant DAN-G-SS-86-0008-88.

2 University of Costa Rica, School of Nutrition. E-mail: enuasucr@cariari.ucr.ac

3 University of Costa Rica, School of Nutrition.
} 


\section{INTRODUCCIÓN}

El comportamiento alimentario de un individuo o de una población está determinado por los conocimientos, actitudes y prácticas que han adquirido a lo largo de su vida (Bourges 1988).

El conocimiento es la fuente de la cual surgen los fines y los motivos de las acciones humanas, ya que por medio de éste se forma el "saber" de los individuos (Calderón 1996.). Por su parte, la actitud es una respuesta determinada del ser humano a las diferentes circunstancias y objetos con los cuales está relacionado, condicionando así su comportamiento (Arellano 1993). Las prácticas alimentarias se adquieren a través de las conductas aprendidas del grupo al que se pertenece y son compartidas por éste (Bourges 1988).

La adquisición de conocimientos y el desarrollo de nuevas actitudes pueden modificar el comportamiento alimentario, sin embargo, este cambio se logra fundamentalmente a través de la práctica (Bourges 1988). Es por ello, que la identificación de los conocimientos, actitudes y prácticas de un grupo determinado de personas con respecto al tema de interés, permite llevar a cabo intervenciones educativas para modificar aquellos inadecuados y reforzar los adecuados.

Campos et al. (1999) hicieron un estudio diagnóstico en la comunidad de Sabanilla de Montes de Oca, en el cual se identificaron los conocimientos, las actitudes y las prácticas de madres de clase media con escolares, en relación a los frijoles. Esta investigación se llevó a cabo como parte del Proyecto "Campaña educativa para incrementar el consumo de frijoles"; con el fin de contar con información para diseñar la mencionada Campaña. Este artículo documenta parte de ese trabajo.

\section{MATERIALES Y MÉTODOS}

El estudio se desarrolló en 1998, en el distrito de Sabanilla de Montes de Oca, una comunidad urbana del Área Metropolitana de Costa Rica. La población estuvo constituida por madres de clase media con niños (as) en edad escolar, de las cuales se obtuvo la participación de 22 informantes clave ${ }^{4}$.

Los conocimientos, las actitudes y las prácticas fueron determinadas utilizando las técnicas de grupo de

4 Personas de la población que se ha definido, que acceden a participar en el estudio cualitativo y que, por lo tanto, no son seleccionadas al azar.

\section{INTRODUCTION}

Alimentary behavior is determined by the knowledge, attitudes and practices acquired by people throughout their lives (Bourges 1988).

Knowledge is the source from which the purposes and motives of human actions derive, because people's "wisdom" comes from knowledge (Calderón 1996). Attitudes are specific responses of human beings to different circumstances and objects with which they are related, thus determining their behavior (Arellano, 1993). Alimentary practices are acquired through learned behaviors from the group to which people belong, and are shared by it (Bourges 1988).

Acquisition of knowledge and the development of new attitudes may modify alimentary behavior. This change is mainly achieved through practice (Bourges 1988). For this reason, identification of the knowledge, attitudes and practices of a specific group of people with regards to a particular issue makes it possible to implement educational actions aimed at modifying the ones that are inadequate and reinforcing those that are adequate.

Campos et al. (1999) made an initial assessment in the community of Sabanilla de Montes de Oca, in which knowledge, attitudes and practices of middleclass mothers of school children with regards to beans were identified. This research was carried out as part of the Project "Educational Campaign to Increase Bean Consumption", with the purpose of gathering the necessary information to design such Campaign. This article documents part of this work.

\section{MATERIALS AND METHODS}

The study was carried out in 1998, in the District of Sabanilla de Montes de Oca, an urban community in the Costa Rican Metropolitan Area. The population for the study was a group of middle-class mothers with school children.

Their knowledge, attitudes and practices with regards to beans were determined through group discussions and semi-structured interviews (Taylor y 1992, Barrantes 1999, Abarca et al. 1996). Group discussions were held with mothers who worked in the house, and interviews with mothers that had jobs outside the house.

Discussion group sessions were held in a classroom at the José Figueres Ferrer School. In total, 
discusión y entrevista semiestructurada (Taylor y Bodgan 1992, Barrantes 1999, Abarca et al. 1996). Los grupos de discusión se realizaron con madres que trabajaban en el hogar y las entrevistas, con madres que trabajaban fuera del hogar.

Los grupos de discusión se realizaron en una aula de una escuela del lugar (Escuela José Figueres Ferrer). En total se realizaron tres sesiones de grupos de discusión en los que participaron 22 madres, que asistieron en grupos de alrededor de siete por sesión.

Para llevar a cabo los grupos de discusión se elaboró la guía correspondiente. Esta guía fue previamente validada en seis grupos de mujeres con características similares a las del grupo en estudio (Campos et al. 1999).

Los grupos de discusión se realizaron con el apoyo de un relator y un moderador, que desempeñaron las funciones descritas para este tipo de técnica (Castro 1992; Abarca et al. 1996; Barrantes 1999).

Las entrevistas semiestructuradas se aplicaron en dos modalidades: entrevistas individuales y grupales. Para realizar estas entrevistas se elaboró una guía que contenía los mismos temas tratados en la guía de grupos de discusión. Se entrevistaron un total de 14 mujeres, de las cuales cuatro realizaron la entrevista grupal.

El análisis de la información obtenida tanto en los grupos de discusión como en las entrevistas semiestructuradas se llevó a cabo utilizando cuadros sinópticos, en los cuales se anotaron las principales respuestas de las participantes. También se rescataron las razones que dieron para sus respuestas y las frases importantes que mencionaron durante la discusión.

\section{RESULTADOS}

Los conocimientos, las actitudes y las prácticas de las madres con respecto a los frijoles se describen a continuación.

\section{CONOCIMIENTOS}

Las madres consideraron como alimentos equivalentes a los frijoles: los cereales y las leguminosas tales como los garbanzos y las arvejas.

\footnotetext{
"Los frijoles son granos como los cereales"

“... pueden ser equivalentes al frijol, las arvejas, las lentejas y los garbanzos"
}

3 sessions were conducted with about seven mothers per session, with participation of 22 mothers.

A guideline that had been previously validated in groups of women with similar characteristics as those of the group studied was used for these sessions. (Campos et al. 1999).

The discussion groups were assisted by a narrator and a moderator who performed the functions described for this type of technique (Castro 1992, Abarca et al. 1996, Barrantes 1999).

Individual and semi-structured group interviews were conducted. A guideline was prepared with the same issues dealt with in the guideline for discussion groups. A total of 14 women were interviewed, out of which 4 participated in a group interview.

The information gathered through discussion groups and semi-structured interviews was analyzed using synoptic tables, listing the main answers from participants. The reasons for their answers, and important phrases they expressed in the discussion were also included.

\section{RESULTS}

The knowledge, attitudes and practices of mothers with regards to beans are described below.

\section{KNOWLEDGE}

Mothers think that cereals and legumes such as chickpeas and split peas are similar to beans.

"Beans are grains like the other cereals"

“... beans may be similar to split peas, lentils and chickpeas"

“... because of my body structure I usually do not eat starchy foods, if I eat rice, I do not eat beans"

Beans were also related to other foods such as liver, spinach and watercress.

“...I would say that beans' nutritional value may be compared to that of liver"

Some mothers think that beans have unique properties that differentiate them from other foods. 
“...yo soy muy quitada por mi contextura a comer mucha harina, si como arroz, no como frijoles"

Los frijoles también se asociaron con otros alimentos como el hígado, las espinacas y los berros.

“... yo diría que en el valor nutritivo se puede comparar con el hígado”

Algunas madres manifestaron que los frijoles tienen características que los diferencian de otros alimentos y los hacen únicos.

“...los frijoles son únicos, nada los sustituye”.

La ventaja que las madres indicaron acerca del consumo de frijoles es su alto valor nutritivo. Algunas reconocieron que son fuente de fibra y de nutrientes específicos como el hierro y el potasio.

“...tienen fibra, que es muy importante, y tienen vitaminas que necesita el organismo”.

Las principales desventajas de consumir frijoles, mencionadas por las madres, se relacionaron con los problemas digestivos que estos podrían ocasionar tales como colitis, gases y cólicos. También opinaron que si se comen en grandes cantidades y acompañados con otras harinas, podrían causar aumento de peso.

"La desventaja que he visto es que a algunas mujeres les causa colitis por el pellejo"

"... los frijoles no engordan tanto si se comen solos en el desayuno..."

Además, manifestaron que consumir frijoles en situaciones específicas, como en periodos postoperatorios podría producir problemas en la cicatrización de las heridas.

“... no se puede comer frijoles después de una operación”

Las madres indicaron que los nutrientes que proveen los frijoles podrían prevenir enfermedades específicas como anemia y estreñimiento. Sin embargo, algunas manifestaron que lo más eficaz para combatir la anemia era consumir el caldo de los frijoles con culantro, ayote o guineo.

"...con un buen caldo de frijol con guineo se ayuda mucho a mejorarse de la anemia”.

Algunas madres dijeron que los frijoles favorecían el crecimiento y el desarrollo del niño, pero concedie-
“... beans are unique, nothing can replace them"

The advantage that mothers indicated about eating beans is that they are highly nutritious. Some acknowledged that they are a source of specific nutrients such as iron, potassium and fiber.

"... they have fiber, which is very important, and vitamins required by the body"

The main disadvantages of consuming beans mentioned by the mothers are related to some digestive problems that they might cause such as colitis, flatulence and colic. They also said that if beans are consumed in large amounts and along with other starchy foods, they might cause people to gain weight.

"The disadvantage I have noticed is that some women get colitis because of beans skin"

" beans are not so fattening if eaten alone for breakfast..."

In addition, the mothers claimed that consuming beans in particular situations such as post-surgery periods might hinder wound healing.

“... people should not eat beans after they have been operated on"

Mothers indicated that nutrients provided by beans may help prevent specific diseases such as anemia and constipation. However, some indicated that the most efficient way to fight anemia is to consume bean broth with cilantro, pumpkin or green bananas.

“... eating a good bean broth with green bananas helps cure anemia"

Some mothers said that beans contribute to children's growth, but they conferred more value to other foods such as meat, milk, grains, fruits and vegetables.

\section{ATTITUDES}

Mothers related consumption of mashed beans to nice memories such as outings, parties and moments shared with the family.

“... what I remember from when I was little is the outings ... we used to bring mashed beans with tortillas..." 
ron una mayor valoración a otros alimentos como carne, leche, granos, frutas y vegetales.

\section{ACTITUDES}

Las madres relacionaron el consumo de frijoles molidos con recuerdos ligados a situaciones agradables como paseos, fiestas y a momentos donde se comparte con la familia.

“...yo de chiquilla lo que me recuerdo era de los paseos...se traían frijoles molidos con tortillas...”

Por otra parte, las madres asociaron los frijoles con el grupo de las harinas y por ende con el aumento de peso, sobre todo cuando se consumían a la hora de la cena.

“ yo prefiero eliminarlos a la hora de la comida (cena) porque engordan"

Las madres prefirieron los frijoles negros, debido a su sabor y a que por tradición son los más utilizados en preparaciones como el gallo pinto y la sopa negra. Sin embargo, también consumían los rojos porque consideraban que los negros son más pesados y causan problemas digestivos.

“... a mi me gustan los negros, pero me dan gastritis y no puedo comer”

\section{PRÁCTICAS}

La mayoría de las madres manifestaron consumir frijoles y casi todas lo hacían diariamente. Las razones que motivaron el consumo se relacionaban con el agrado por los frijoles, la valoración de este grano como un alimento nutritivo, así como por costumbre y tradición. También señalaron la facilidad para incorporarlo en el menú diario.

“...los frijoles son muy ricos, llenan y nutren un poco"

“... con cualquier cosa se acompañan y se hace un casado”

Las madres que no consumían frijoles, manifestaron que la principal razón para no hacerlo es que todos los tipos de frijoles les causaban algún problema digestivo. Sin embargo, esta no fue la única razón, ya que además indicaron que este alimento es harinoso y que por ello engorda.

“...en mi casa si se consumen frijoles, pero conozco gente que no come porque dicen que engordan”
On the other hand, mothers associated beans with starchy foods causing people to gain weight, mainly when consumed at dinner time.

"I rather not to eat beans at dinner time because they can make you fat..."

In general, mothers preferred black beans because of their taste, and also because they are the ones traditionally used for gallo pinto and bean soup. However, they also consumed red beans because they think that black beans are more difficult to digest.

“... I like black beans, but they give me gastritis and I cannot eat them"

\section{PRACTICES}

Most mothers said that they eat beans, and almost all of them do it daily. The reasons for them to eat beans were that they liked them, they acknowledged their nutritional value; and also that they eat them out of habit and tradition. They also indicated that it was easy to integrate beans into their daily menu.

“... beans are delicious, they are filling and a little bit nutritious"

"... you can eat beans with anything else, and make a 'casado' (a typical meal)"

In the cases of mothers that did not eat beans, the main reason was that all types of beans cause them some type of digestive problem. However, this was not the only reason, because they also indicated that beans are a starchy food and because of that, they are fattening.

"...we eat beans at home, but I know people who don't eat them because they say that beans are fattening"

They also mentioned the fact that since cooking beans is such a tedious chore, this is an obstacle for consumption.

With regards to meal times in which participants ate beans, it was determined that beans were mostly eaten for lunch, although some mothers also eat them for breakfast and dinner. Women ate less beans at dinner time because they considered that at night they are more difficult to digest, and cause people to gain weight. 
También indicaron que una limitante para el consumo de frijoles es el tedioso proceso de cocción.

Con respecto a los tiempos de comida en los cuales las participantes incluían frijoles, se determinó que es en el almuerzo cuando más consumían este grano, aunque algunas madres también lo hacían en el desayuno y la cena. En la cena, el consumo fue menor, porque consideraban que en la noche caían pesados y causaban aumento de peso.

“...en la cena no, porque prefiero algo más liviano"

“...si, sólo al almuerzo no en la comida porque todos estamos muy gorditos"

Las madres consumían los frijoles principalmente en la casa y en el trabajo. Las preparaciones usuales de frijoles son sopa negra, molidos, fritos, frescos con el caldo, arreglados y en gallo pinto.

“... el primer día me gusta comerlos frescos, pero al segundo día los licúo y los arreglo"

El gallo pinto es una preparación preferida para el desayuno durante los fines de semana. Muchas madres refirieron que entre semana no tenían suficiente tiempo para hacer el desayuno y que sólo podían prepararlo los fines de semana y días feriados, debido a que es una receta laboriosa.

“... en casa se hace al desayuno el gallo pinto, más que todo el fin de semana”

Algunas de las madres manifestaron que de vez en cuando preparaban algunas de las siguientes recetas: burritos, tamal de frijol, empanadas de plátano maduro con frijoles, chalupas, taquitos y molletes.

Los frijoles se sirven acompañados principalmente por preparaciones como arroz, carne y ensalada. También mencionaron tortillas, pan, picadillos, guineo, plátano maduro y fresco natural.

"Pues, con lo que haya para comer: carne, arroz, ensalada"

Algunas madres manifestaron que no combinaban los frijoles con otras preparaciones harinosas como pastas o tubérculos, pues consideraban que muchas harinas pueden causar aumento de peso.

"Cuando se hace espagueti no se comen frijoles"

Todas las participantes compraban los frijoles crudos y preferían los que se expenden escogidos y
“... I do not eat them for dinner because I rather eat something lighter"

“... yes, we only eat them for lunch because we are very fat"

Mothers consumed beans mainly at home and at work. Usual preparations with beans included black bean soup, mashed beans, refried beans, beans recently cooked in their broth, seasoned beans and in gallo pinto.

“... the first day I like to eat them as they are just cooked, but on the second day I put them in the blender and season them"

Gallo pinto is a favorite dish for breakfast during the weekends. Many mothers said that they do not have enough time to make breakfast during the week and therefore, they can only make gallo pinto on weekends and holidays because it is time-consuming.

“... we make 'gallo pinto' for breakfast mostly on weekends"

Some of the recipes that mothers prepare occasionally are: burritos, bean tamale, ripe plantain with beans, chalupas, tacos and molletes.

In particular, beans are served with rice, meat and salads. Other foods mentioned are tortillas, bread, minced vegetables, green bananas, ripe plantain and fruit beverages.

"I eat them with whatever there is to eat: meat, rice, salad"

Some mothers said they prefer not to mix beans with other starchy foods such as pasta or tubers, because they consider that eating a lot of starchy foods causes people to gain weight.

"When we make spaghetti, we do not eat beans"

All the mothers participating in the study buy raw beans, and they choose the ones that look freshly packed and are ready to cook. Consumption of canned beans was mostly mentioned by mothers working outside the house.

Participants said they store raw beans in the cupboard, either in the bag in which they come or in a plastic container. In some cases they add garlic and black pepper, among other things, to keep bugs away for longer periods of time. 
frescos. El consumo de frijoles enlatados fue mencionado con mayor frecuencia por el grupo de madres que trabajaban fuera del hogar.

Las participantes manifestaron que guardaban los frijoles crudos en la alacena, ya sea en la misma bolsa o en un recipiente plástico. En algunos casos les adicionaban ajo y pimienta, entre otras cosas, para preservarlos por más tiempo.

“..en un tarro en la alacena”

“... para que no se llene de animalitos es bueno meterles unos cuantos dientes de ajo"

En relación con los procedimientos previos a la cocción, la mayoría de las madres lavaban los frijoles antes de cocinarlos. La práctica de escoger los frijoles se detectó principalmente en mujeres que trabajaban en el hogar. En el caso de las mujeres que trabajaban fuera del hogar esta práctica no se llevaba a cabo, porque compraban los frijoles limpios y escogidos.

\section{"yo los compro escogidos...no me complico la vida"}

La mayoría de las madres no remojaban los frijoles debido a la falta de tiempo y a que no conocían los beneficios que esa práctica conlleva. Las pocas madres que realizaban esa práctica aseguraron que ahorraban tiempo y electricidad, pero desconocían los efectos positivos del remojo para mejorar la digestibilidad y el valor nutritivo de los frijoles.

Entre los condimentos que adicionaban en la cocción, mencionaron principalmente condimentos naturales tales como cebolla, ajo, culantro y orégano; y condimentos artificiales como salsa inglesa y cubitos sazonadores. Algunas madres adicionaban la sal antes de la cocción y otras cuando ya estaban cocidos. En muchos casos condimentaban los frijoles después de cocinarlos con diversos ingredientes como aceite o mantequilla, condimentos naturales y condimentos artificiales. Esta práctica es conocida popularmente como "arreglar los frijoles".

La mayoría de las madres manifestaron que cocinaban los frijoles en olla de presión, la olla de cocimiento lento y la olla convencional eran utilizadas en segundo y tercer lugar respectivamente. Las razones que las participantes adujeron para utilizar cada tipo de olla son el sabor que adquirían los frijoles durante la cocción y la facilidad que les brindaba cada tipo de olla. Las madres que empleaban la olla de presión consideraron que el tiempo de cocción de los frijoles era más corto que cuando se cocinaban en olla convencional. Las madres que los cocinaban en la olla de cocimiento lento refirieron que el tiempo requerido para cocinarlos no les afectaba,
"... in a pot in the cupboard"

"... it is good to put in some garlic, so that beans do not get infested with bugs"

Regarding methods used before cooking the beans, most mothers washed them. The practice of selecting the grains before cooking them is used mostly by mothers that work at home, but women working outside did not use this practice because they usually buy beans that are ready to cook.

\section{"I buy them ready... I do not complicate myself"}

Most women did not soak the beans in water because they did not have time or ignored the benefits of this practice. The few mothers that used this practice said that it saves them time and electricity, but they ignored the positive effects of soaking the beans in water, to improve digestibilidad and nutritional value.

Natural seasonings such as onion, garlic, cilantro and oregano are among the most frequently mentioned seasonings added to beans to cook them, while the artificial seasonings mentioned were salsa inglesa and bouillon cubes. Some mothers added salt before cooking them, and others after they were cooked. In many cases, beans were seasoned after they were cooked, with ingredients such as oil or butter, and natural and artificial seasonings. This practice is popularly known as "seasoning the beans".

Most mothers said that they use the pressure cooker to make the beans, while use of a slow cooker and conventional cooking pot are in second and third place respectively. The reasons given by mothers to use either of the utensils were related to the taste beans acquired during cooking, and to how each type of pot facilitates the cooking process. Mothers using the pressure cooker considered that it took less time than when using a conventional pot. Mothers that use the slow cooker said that the time required to make the beans does not affect them, because they do not need to watch over the process, and it did not interfere with other housekeeping chores (Campos et al. 1999).

"... in the pressure cooker it takes 10 minutes"

".. I use the slow cooker because I am not in a hurry"

Most mothers mentioned that they keep cooked beans in the refrigerator, in a covered container. They also mentioned other methods such as boiling the beans every day or keeping them in the freezer.

"... I keep them in the refrigerator, in a plastic container" 
ya que este implemento no requería supervisión continua y no interfería con las demás labores domésticas (Campos et al. 1999).

"... en la olla de presión duran 10 minutos"

“... yo cocino en la olla de cocimiento lento, porque a uno no le precisa"

La mayoría de las madres mencionaron que conservaban los frijoles cocidos en el refrigerador, en un recipiente con tapa. También mencionaron otros métodos, como hervirlos diariamente o guardarlos en el congelador. plástico”

“... yo los mantengo en la refri, en un recipiente de

\section{DISCUSIÓN}

El estudio confirmó que los frijoles constituyen un alimento básico en la alimentación del costarricense. Estudios como el de Robertson (1995) y Abarca et al. (1996), reflejaron que este alimento sigue formando parte de los hábitos alimentarios del costarricense.

La Encuesta Nacional de Nutrición de 1996 determinó que el 96,7 \% de los costarricenses consumen este grano. Sin embargo, en la zona urbana, la cantidad de frijoles que se consume ha disminuido gradualmente, alcanzando alrededor de 20 gramos menos de frijoles por persona por día, en un período de 30 años (INCAP/ICNND/ Ministerio de Salubridad Pública de Costa Rica 1969; Ministerio de Salud 1996).

\section{CONOCIMIENTOS}

Las madres expresaron que consumir frijoles induce al aumento de peso. Por el contrario, los frijoles, por su alto contenido de fibra previenen el estreñimiento y producen saciedad, lo que evita el consumo excesivo de alimentos y por ende ayuda a mantener un peso adecuado (Mahan y Escott-Stump 2001).

La mayoría de las madres compararon correctamente los frijoles con otras leguminosas y otros alimentos fuentes de hierro. Por el contrario, otras madres hicieron comparaciones incorrectas al indicar que eran similares a los cereales y a otros alimentos harinosos, lo que refuerza la creencia errada de que los frijoles engordan. En el estudio de Abarca et al. (1996) se obtuvo un resultado similar, ya que las participantes percibieron los frijoles como un alimento harinoso, cuyo principal aporte eran los carbohidratos.

\section{DISCUSSION}

The study confirmed that beans are a staple food in the diet of Costa Ricans. Studies such as the one by Robertson (1995) and Abarca et al. (1996), show that this food continues to be an integral part of alimentary habits in this country.

According to the 1996 National Nutrition Survey 96.7\% of Costa Ricans consume beans. However, consumption has gradually decreased in urban areas, reaching about 20 grams less per person per day, over a 30-year period (INCAP/ICNND/Ministerio de Salubridad Pública de Costa Rica 1969, Ministerio de Salud 1996).

\section{KNOWLEDGE}

Mothers claimed that eating beans made them gain weight. Instead, due to their high fiber content beans help prevent constipation and make people feel satiated for longer periods of time, which prevents them from eating excessively, thus helping them to maintain an adequate weight (Mahan and Escott-Stump 2001).

Most mothers were able to make correct comparisons of beans with other legumes and iron-rich foods. However, others compared them with cereals and starchy foods, which is a misconception that reinforces the belief that beans are fattening.

Similar results were obtained in the study by Abarca et al. (1996), because participants perceived beans as a starchy food, whose main contribution consists of carbohydrates.

For many decades people have been taught that beans are within the group of "cereals, legumes, and starchy vegetables", information that is still provided in the "Guías Alimentarias para Costa Rica" ("Alimentary Guidelines for Costa Rica") (Ministerio de Salud 1997), which favors that misconception. The importance that mothers assign to other foods such as meats, fruits, grains and cheese show the lack of knowledge and the general low appreciation of beans.

It is not convenient to classify beans within that food group, because it might misrepresent their nutritive value. In the nutritional pyramid and similar guidelines for other countries (Department of Agriculture 1996), beans are classified together with meats, due to their great nutritional contribution. But even if beans are a good source of carbohydrates and 
La enseñanza que se ha impartido durante muchas décadas y que aún continúa con las "Guías Alimentarias para Costa Rica" (Ministerio de Salud 1997), que ubica los frijoles dentro del grupo de "cereales, leguminosas y verduras harinosas", ha propiciado esta creencia. La importancia que le dieron las madres a alimentos como la carne, las frutas, los granos y el queso refleja la falta de conocimiento y poca valoración que tenían de los frijoles. No es conveniente que este alimento se ubique dentro de ese grupo, porque puede distorsionar la percepción sobre su valor nutritivo. La pirámide nutricional y otras guías similares para otros países (Deparment of Agriculture 1996) lo ubican junto con las carnes por el elevado aporte nutricional de los frijoles. Es necesario hacer énfasis en que a pesar de que los frijoles constituyen una rica fuente de carbohidratos y energía, su aporte de proteínas, vitaminas, minerales y fibra, los convierten en un alimento funcional y alternativo de las carnes (Sedó 2001).

Otra desventaja mencionada por las madres es que el consumo de este alimento retrasa la cicatrización de heridas, lo cual es un conocimiento erróneo, ya que los frijoles tienen una alta cantidad de proteínas, las cuales favorecen la formación de nuevo tejido y por ende, la cicatrización de las heridas (Torún et al. 1994).

A pesar de que algunas madres combinaban los frijoles con carnes y alimentos fuente de vitamina $\mathrm{C}$, no conocían los beneficios que brinda esta práctica con respecto a la biodisponibilidad de hierro, ya que no se ha dado orientación nutricional sobre este tema. Transmitir esta información podría contribuir a fomentar esta práctica.

El conocimiento de que el caldo de frijoles con guineo es nutritivo obedece a una creencia popular existente en nuestra población (Robertson 1995), pero carente de veracidad por la baja densidad nutricional del caldo y porque el guineo no es fuente de hierro (Murillo y Ulate 1984).

\section{ACTITUDES}

Se identificaron tanto actitudes positivas como negativas con respecto a los frijoles. Las actitudes positivas que tenían las madres estaban asociadas a las experiencias agradables en relación a los frijoles molidos vividas desde la niñez y las negativas con la creencia de que engordan, como ya ha sido discutido.

Los frijoles eran incluidos en los principales tiempos de comida (desayuno, almuerzo y cena). No obstante, en la cena eran menos utilizados ya que las madres consideraban que el consumo de frijoles en este energy, their protein, vitamin, mineral and fiber content, make them a functional food which could be used as an alternative to meats (Sedó 2001).

Another disadvantage mentioned by mothers is that eating beans delays wound healing processes, which is a misconception, because in fact they provide a great amount of proteins that favor formation of new tissue, thus favoring wound healing (Torún et al. 1994).

In spite of the fact that some mothers combine beans with meats and other foods that are a source of vitamin $\mathrm{C}$, they actually ignore the benefits that this practice provides with regards to iron availability. This is due to the fact that there has been a lack of nutritional orientation on the subject. Disseminating this information might contribute to promote this practice.

In Costa Rica there is a popular belief that bean broth combined with green bananas is nutritious. This is a misconception, because of the low nutritional density of the broth and because green bananas are not a source of iron, as people believe (Murillo and Ulate 1984).

\section{ATTITUDES}

Positive and negative attitudes with regards to beans were identified. The positive attitudes of mothers were related to nice experiences from their childhood, and the negative ones were related to the belief that beans are fattening, as has been discussed.

Beans were served in the main meal times (breakfast, lunch and dinner). However, women eat them less frequently for dinner, because they think that eating them at night may cause them to gain weight and provoke digestive problems. This attitude limits bean consumption.

Black beans were the favorite type of beans in the group studied. Women also ate red beans because they caused them less discomfort. Experts on the issue claim that certain relationship may exist between bean color and their digestibility, due to a greater content of tannins and polyphenolic substances present in darker beans when they are cooked (Hoppner and Lamp 1993).

\section{PRACTICES}

The cooking process was a barrier to bean consumption because it takes time that in many cases 
tiempo de comida podría tener efectos negativos relacionados con el aumento de peso y la dificultad para digerirlos durante la noche. Esta actitud es una limitante en el consumo de este alimento.

En el grupo estudiado los frijoles negros fueron los preferidos. Los frijoles rojos también se consumían porque causaban menos malestar. Expertos en la materia aseguran que podría existir cierta relación entre el color de los frijoles y su digestibilidad, debido al mayor contenido de taninos y sustancias polifenólicas presentes en los frijoles cocidos más oscuros (Hoppner y Lamp 1993).

\section{PRÁCTICAS}

El proceso de cocción resultó ser una barrera para el consumo de este grano, ya que requiere de tiempo de la madre, el cual en muchos casos es limitado. Además, en la zona urbana costarricense las familias son actualmente más pequeñas que en el pasado (Gómez 1995); por lo que no necesitan cocinar frijoles en grandes cantidades. Sin embargo, el gasto de energía y tiempo que demanda cocinar frijoles, no se justifica si se cocinan en poca cantidad. Cualquier abordaje educativo que tienda a promover el consumo de este alimento debe tomar en cuenta este aspecto.

Las madres combinaban muchos alimentos con los frijoles. Cabe destacar la combinación con carnes y alimentos fuentes de vitamina $\mathrm{C}$ como ensaladas, lo cual resulta beneficioso para mejorar la biodisponibilidad del hierro contenido en los frijoles (Torún et al. 1994).

Los frijoles molidos enlatados, eran utilizados principalmente por las madres que trabajaban fuera del hogar. Posiblemente esto se debe a que este grupo de mujeres cuenta con menos tiempo para la preparación de alimentos y encuentra en los frijoles molidos enlatados una opción sencilla y rápida para consumir esta leguminosa. Este sería un grupo que podría mostrar interés en la adquisición de frijoles en polvo deshidratados, tal como el producto formulado en el Centro de Investigación en Tecnología de Alimentos ${ }^{5}$. Un estudio de mercado ${ }^{6}$ desarrollado como parte de este mismo proyecto para un producto similar, demostró que hay gran aceptación por parte de diferentes grupos etáreos (niños (as), madres y adultos mayores) debido a los beneficios nutricionales que éste puede ofrecer y a las facilidades para su preparación.

\footnotetext{
5 Bonilla, A. 1999. Frijoles. Investigadora Centro de Investigacione en Tecnología de Alimentos. Comunicación personal.

6 Como parte del Proyecto "Campaña Educativa ....", se ofreció una asesoría para el mercadeo de frijol deshidratado
}

was limited for mothers. In addition, families in the Costa Rican urban areas are usually smaller than they used to be (Gómez 1995), and therefore they do not need to cook beans in large amounts. And yet, since making beans demands a great deal of time and energy, making small amounts is not worth the effort. Any educational approach aimed at promoting bean consumption must take this limitation into account.

Mothers combined many other foods with beans, such as meats and other foods high in vitamin $\mathrm{C}$, such as salads. This improves bioavailability of iron provided by beans (Torún et al. 1994).

Canned mashed beans were mainly used by mothers working outside the house. Perhaps, this is due to the fact that they have less time to prepare the meals, and canned beans represent a simple and fast way to consume them. For this reason, this group may show interest in buying the dehydrated powdered beans formulated at the Centro de Investigación en Tecnología de Alimentos 5 (the Food Technology Research Center). A marketing study 6 developed as part of this Project for a similar product showed that the different age-groups (children, mothers and the elderly) widely accept this formulation due to the nutritional benefits it may provide and its convenient preparation.

Only a few mothers had the habit of soaking the beans before cooking them. This practice is recommended because it allows reduction of cooking time, which facilitates bean preparation and favors conservation of their nutritional value (FAO 1990). In addition, if the water used to soak the beans is thrown away, anti-nutritional substances that may cause gastric problems to some people, are also discarded (FAO 1990). However, the soaking water also contains dissolved nutritional substances which are lost when discarding this water. For this reason, this practice is only recommended for people that continue to have digestive problems when eating beans, even when they have been soaked.

Some mothers added salt to the beans before cooking them. This practice is not recommended because in this way they take more time to cook; in addition more salt is required to achieve the desired taste (Dumani and Rodríguez 2000).

Using natural seasonings to prepare or "season" beans is beneficial because it helps increase their nutritional value and improve their taste. On the

\footnotetext{
5 Bonilla, A. 1999. Beans. Researcher Centro de Investigaciones en Tecnología de Alimentos (CITA). Personnal interview.

6 As part of the Project "Educational Campaign...", a consultant ship was offered to market dehydrated beans.
} 
Remojar los frijoles antes de cocinarlos, es una práctica que realizaban muy pocas madres. Esta práctica debe recomendarse ya que este proceso disminuye el tiempo de cocción, lo que facilita su preparación y ayuda a conservar su valor nutritivo (FAO 1990). Además, si se desecha el agua utilizada para remojar los frijoles, también se eliminan sustancias antinutritivas que pueden producir en algunas personas problemas gástricos (FAO 1990). Sin embargo, en el agua de remojo, también hay sustancias nutritivas en solución que se pierden al desechar el agua de remojo, por lo que esta práctica sólo es recomendable para aquellas personas que aún remojando los frijoles, continúan presentando problemas digestivos al consumirlos.

Algunas madres adicionaban la sal al iniciar la cocción de los frijoles. Esta práctica no se recomienda, ya que aumenta el tiempo requerido para la cocción; además la cantidad de sal requerida para dar la sazón deseada es mayor que la que se necesita para los frijoles ya cocidos (Dumani y Rodríguez 2000).

La utilización de condimentos naturales para preparar o "arreglar" los frijoles resulta beneficioso, ya que esto ayuda a aumentar el valor nutritivo de los mismos y a potenciar su sabor. Por el contrario, el uso de grasa y de condimentos artificiales no es conveniente, porque aumenta el valor energético de la preparación y podría causar problemas digestivos como gastritis y colitis.

La mayoría de las madres utiliza la olla de presión para cocinar los frijoles, lo cual es adecuado ya que mejora su digestibilidad y evita la pérdida excesiva de nutrientes, debido a la rápida cocción. Lo contrario ocurre con la olla de cocimiento lento y con la olla convencional. La cocción prolongada o excesiva reduce en forma progresiva la calidad proteica, debido a la destrucción de aminoácidos esenciales y provoca la pérdida de algunas vitaminas. Es importante destacar la pérdida de ácido fólico que ocurre progresivamente conforme aumenta el tiempo de cocción (Hoppner y Lamp 1993; Dang et al. 2000).

De los métodos que utilizaban para conservar los frijoles cocidos, la refrigeración y la congelación son contrary, using fat and artificial seasonings is not recommended because it increases their energetic value and causes digestive problems such as gastritis and colitis.

Most mothers used the pressure cooker to prepare beans. This is an adequate practice because it improves their digestibility; besides, less nutrients are lost because beans cook faster. The contrary happens with the slow cooker and conventional pot. Cooking the beans for a long period or excessively, reduces their protein quality, because essential amino acids are destroyed and some vitamins are lost. It is important to emphasize on the loss of folic acid that takes place progressively as the cooking time increases (Hoppner, and Lamp 1994; Dang et al. 2000).

Of all the methods used to preserve cooked beans, refrigeration and freezing are the most adequate. Freezing beans is the best way to keep them because it increases their useful life and in this way beans are permanently available. This is important in small families, which currently prevail (Gómez 1005). These families must cook the beans in large amounts in order to make a better use of the time and energy required. Then they can freeze beans to preserve them for longer periods of time. Boiling the beans every day is not an adequate practice, because they contain thermo-labile nutrients like thiamine and folic acid that are lost every time they are subjected to high temperatures (Hoppner and Lamp 1993; Torún et al. 1994).

In conclusion, although beans are commonly consumed by the population, inadequate knowledge, attitudes and practices were detected that represent barriers to bean consumption and to the preservation of their nutritional value.

The results of this study provide useful information to design educational messages that are in agreement with the population's needs with regards to this subject. Another valuable contribution for message design is the additional information obtained with regards to the popular language used to refer to bean handling and consumption. 
los más adecuados. Este último es el mejor, ya que aumenta la vida útil y permite la disponibilidad permanente de este alimento, lo cual es importante en el caso de familias pequeñas, que son las que predominan en la actualidad (Gómez 1995). Es recomendable que estas familias, cocinen los frijoles en cantidades grandes, para optimizar tiempo y energía y los conserven congelados. De esta manera pueden conservarlos por periodos más largos. El método de hervir los frijoles diariamente, mencionado por varias madres es inadecuado, debido a que los frijoles contienen nutrientes termolábiles que se pierden cada vez que el alimento se somete a temperaturas elevadas, tal es el caso de la tiamina y el ácido fólico (Hoppner y Lamp 1993; Torún et al. 1994).

En conclusión, aunque los frijoles son un alimento de uso común por la población, se detectaron conocimientos, actitudes y prácticas inadecuadas que constituyen barreras que afectan su consumo y la preservación de su valor nutritivo.

Los resultados obtenidos en este estudio proporcionan información de gran utilidad para elaborar mensajes educativos que correspondan con lo que la población requiere alrededor de esta temática. Otro aporte valioso para la construcción de mensajes es el rescate del lenguaje comúnmente utilizado por la población en torno a este alimento.

\section{LITERATURA CITADA}

ABARCA, L; CHÁVEZ, D; DUMANI, M; ELIZONDO, F; FLORES, R; RIGGIONI, R. 1996. Prácticas alimentarias de seis grupos de mujeres de la gran Área Metropolitana. Seminario Lic. San José, Costa Rica: Universidad de Costa Rica. 161p.

ARELLANO, R. 1993. Comportamiento del consumidor y marketing. México: McGraw Hill Interamericana. p. 265.

BARRANTES, E. 1999. Investigación: un camino al conocimiento, un enfoque cualitativo y cuantitativo. San José, Costa Rica: EUNED. p. 264.

BOURGES, H. 1988. Costumbres, prácticas y hábitos alimentarios deseables e indeseables. Archivos Latinoamericanos de Nutrición 39 (3): 767-779.

CALDERÓN, E. 1996. Conocimientos, actitudes y prácticas de madres en la alimentación de niños (as) preescolares en la comunidad de Las Tapias, Guatemala. Guatemala: OPS / INCAP. p. 84.

CAMPOS, E; FERNÁNDEZ, A; SÁNCHEZ, I; SANCHO, T; VILLALOBOS, C. 1999. Diagnóstico para el diseño de una Campaña educativa tendiente a incrementar el consumo de frijol en una comunidad urbana de clase media de Costa Rica. Seminario Lic. San José, Costa Rica: Universidad de Costa Rica. 153 p.

\section{REFERENCES}

ABARCA, L; CHÁVEZ, D; DUMANI, M; ELIZONDO, F; FLORES, R; RIGGIONI, R. 1996. Prácticas alimentarias de seis grupos de mujeres de la gran Área Metropolitana. Seminario Lic. San José, Costa Rica: Universidad de Costa Rica.161p.

ARELLANO, R. 1993. Comportamiento del consumidor y marketing. México: McGraw Hill Interamericana. p. 265.

BARRANTES, E. 1999. Investigación: un camino al conocimiento, un enfoque cualitativo y cuantitativo. San José, Costa Rica: EUNED. p. 264.

BOURGES, H. 1988. Costumbres, prácticas y hábitos alimentarios deseables e indeseables. Archivos Latinoamericanos de Nutrición 39 (3): 767-779.

CALDERÓN, E. 1996. Conocimientos, actitudes y prácticas de madres en la alimentación de niños (as) preescolares en la comunidad de Las Tapias, Guatemala. Guatemala: OPS / INCAP. p. 84.

CAMPOS, E; FERNÁNDEZ, A; SÁNCHEZ, I; SANCHO, T; VILLALOBOS, C. 1999. Diagnóstico para el diseño de una Campaña educativa tendiente a incrementar el consumo de frijol en una comunidad urbana de clase media de Costa Rica. Seminario Lic. San José, Costa Rica: Universidad de Costa Rica.153 p.

CASTRO, A. 1992. Estrategias de enseñanza Módulo 4. Programa de Formación Docente Pedagógica. PAITEXOPS-OMS. p. 75

DANG, J, ARCOT, J; SHRESTHA, A. 2000. Folate retention in selected processed legumes. Food Chemistry, 68: 295-298.

DEPARMENT OF AGRICULTURE. UNITED STATES. 1996. The food guide pyramid. Home and Garden Bulletin, 256.

DUMANI, M; RODRÍGUEZ, S. 2000. De todo con frijoles. Universidad de Costa Rica, Escuela de Nutrición/ CITAPrograma Bean Cowpea CRSP-AID. San José, Costa Rica: Diseño y arte Amón. p.35.

FAO. 1990. Utilización de alimentos tropicales: frijoles tropicales. (47/4). Italia, Roma: Organización de Las Naciones Unidas para la Agricultura y la Alimentación. p. 80.

GÓMEZ, V. 1995. Actualidad demográfica 1994. San José, Costa Rica: FNUAP. p. 137.

HOPPNER, K; LAMP, B. 1993. Folate retention in dried legumes after different methods of meal preparation. Food Research International 26: 45-48.

INCAP/ICNND/ MINISTERIO DE SALUBRIDAD PÚBLICA DE COSTA RICA. 1969. Evaluación nutricional de 
CASTRO, A. 1992. Estrategias de enseñanza Módulo 4. Programa de Formación Docente Pedagógica. PAITEXOPS-OMS. p. 75.

DANG, J, ARCOT, J; SHRESTHA, A. 2000. Folate retention in selected processed legumes. Food Chemistry, 68: 295-298.

DEPARMENT OF AGRICULTURE. UNITED STATES. 1996. The food guide pyramid. Home and Garden Bulletin, 256.

DUMANI, M; RODRÍGUEZ, S. 2000. De todo con frijoles. Universidad de Costa Rica, Escuela de Nutrición/ CITAPrograma Bean Cowpea CRSP-AID. San José, Costa Rica: Diseño y arte Amón. p.35.

FAO. 1990. Utilización de alimentos tropicales: frijoles tropicales. (47/4). Italia, Roma: Organización de Las Naciones Unidas para la Agricultura y la Alimentación. p. 80.

GÓMEZ, V. 1995. Actualidad demográfica 1994. San José, Costa Rica: FNUAP. p. 137.

HOPPNER, K; LAMP, B. 1993. Folate retention in dried legumes after different methods of meal preparation. Food Research International 26: 45-48.

INCAP/ICNND/ MINISTERIO DE SALUBRIDAD PÚBLICA DE COSTA RICA. 1969. Evaluación nutricional de la población de Centroamérica y Panamá: Costa Rica. Publicación INCAP-V-28. Guatemala, Guatemala: INCAP. 113 p.

MAHAN, K; ESCOTT-STUMP, S. 2001. Nutrición y dietoterapia de Krause. $10^{\text {th }}$ ed. México, D:F, McGraw-Hill Interamericana. p. 1274.

MINISTERIO DE SALUD. 1996. Encuesta Nacional de Nutrición. Fascículo 3: Consumo Aparente. San José, Costa Rica. p. 45.

1997. Guías alimentarias para la educación nutricional en Costa Rica. San José. Costa Rica. p. 90.

MURILLO, S; ULATE, E. 1984. Composición de alimentos y tabla de pesos para Costa Rica. San José, Costa Rica: Departamento de publicaciones de la Universidad de Costa Rica. p. 47.

ROBERTSON, A. 1995. Conocimientos, actitudes y prácticas de las madres en relación con alimentos fuente de hierro en la dieta de los niños (as) menores de tres años en un área rural y urbana de la provincia de San José. Tesis de Licenciatura. San José, Costa Rica: Universidad de Costa Rica.103 p.

SEDÓ, P. 2001. Alimentos funcionales: análisis general acerca de las características químico-nutricionales, desarrollo industrial y legislación alimentaria. Rev. Costarricense de Salud Pública Año 10, Nº 18 y19: 34-39.

TAYLOR, SJ; BODGAN, R. 1992. Introducción a los métodos cualitativos de investigación. Barcelona, España: Ediciones PAIDOS. p. 329.

TORÚN, B; MENCHÚ, M; ELÍAS, L. 1994. Recomendaciones dietéticas diarias del INCAP. Guatemala: INCAP/ OPS. p. la población de Centroamérica y Panamá: Costa Rica. Publicación INCAP-V-28. Guatemala, Guatemala: INCAP. 113 p.

MAHAN, K; ESCOTT-STUMP, S. 2001. Nutrición y dietoterapia de Krause. $10^{\text {th }}$ ed. México, D:F, McGraw-Hill Interamericana. p. 1274.

MINISTERIO DE SALUD. 1996. Encuesta Nacional de Nutrición. Fascículo 3: Consumo Aparente. San José, Costa Rica. p. 45.

1997. Guías alimentarias para la educación nutricional en Costa Rica. San José. Costa Rica. p. 90.

MURILLO, S; ULATE, E. 1984. Composición de alimentos y tabla de pesos para Costa Rica. San José, Costa Rica: Departamento de publicaciones de la Universidad de Costa Rica. p. 47.

ROBERTSON, A. 1995. Conocimientos, actitudes y prácticas de las madres en relación con alimentos fuente de hierro en la dieta de los niños (as) menores de tres años en un área rural y urbana de la provincia de San José. Tesis de Licenciatura. San José, Costa Rica: Universidad de Costa Rica.103 p.

SEDÓ, P. 2001. Alimentos funcionales: análisis general acerca de las características químico-nutricionales, desarrollo industrial y legislación alimentaria. Rev. Costarricense de Salud Pública Año 10, № 18 y19: 34-39.

TAYLOR, SJ; BODGAN, R. 1992. Introducción a los métodos cualitativos de investigación. Barcelona, España: Ediciones PAIDOS. p. 329.

TORÚN, B; MENCHÚ, M; ELÍAS, L. 1994. Recomendaciones dietéticas diarias del INCAP. Guatemala: INCAP / OPS. p. 